Article

\title{
Financial Inclusion, Socioeconomic Disaster Risks and Sustainable Mountain Development: Empirical Evidence from the Karakoram Valleys of Pakistan
}

\author{
Kifayat Ullah ${ }^{1, *}$, Abdul Qayyum Mohsin ${ }^{1}$, Abdul Saboor ${ }^{1, *}$ and Saranjam Baig ${ }^{2}$ (1) \\ 1 Department of Economics and Agriculture Economics, Pir Mehr Ali Shah Arid Agriculture University, \\ Muree Road, Shamsabad, Rawalpindi 46000, Pakistan; drmohsin_aq@hotmail.com \\ 2 College of Economics and Political Science, Sultan Qaboos University, Muscat 999046, Oman; \\ s.baig1@squ.edu.om \\ * Correspondence: kifayat@kiu.edu.pk (K.U.); drabdul.saboor@uaar.edu.pk (A.S.)
}

Received: 5 October 2020; Accepted: 10 November 2020; Published: 22 November 2020

\begin{abstract}
Does financial inclusion contribute to sustainable mountain development by providing access to financial resources and creating economic opportunities for poor mountain people? Keeping this question in mind, the present study aimed to investigate the nexus between financial inclusion and improvement in the living standards of mountain people, and reduction in socioeconomic disaster risks (economic poverty, multidimensional poverty and income inequality). For empirical investigation, the study employed Quasi Experimental Designs, Foster, Greer and Thorbecke poverty measures, Alkire et al. methodology, Gini Index and Quintile technique to assess the impact of financial inclusion on the living standards and reduction of economic poverty, multidimensional poverty and income inequality, respectively. We used the Logistic Regression technique to identify major drivers of socioeconomic disaster risks in the study area. The study collected quantitative and qualitative household level data from 424 households through structured questionnaires using multistage sampling technique for analysis. The findings of the study revealed a positive synergy among inclusive finance and living standards and a negative connection between financial inclusion and socioeconomic disaster risks in the Karakoram valleys of Pakistan. The logistic regression results also recognized financial inclusion as a potential determinant of economic poverty reduction. However, financial inclusion as a potential tool to eradicate multidimensional poverty in the study area showed insignificant results. These findings can help policy-makers and other stakeholders to understand the dynamics of socioeconomic disaster risks and the role of financial inclusion in their reduction to accomplish sustainable mountain development in the Karakoram valleys of Pakistan.
\end{abstract}

Keywords: financial inclusion; socioeconomic disaster risks; sustainable mountain development; Pakistan

\section{Introduction}

Holding $28 \%$ of the world forests share, mountain areas have huge potential for carbon storage and play a critically important role in the global green economy, i.e., "an economy where economic growth is accompanied by reduced carbon emissions and pollution, reduced rates of poverty and income inequality, enhanced energy and resource efficiency and maintained ecosystem services including biodiversity" [1-3]. Covering $27 \%$ of the global earth surface and by providing 60 to 80 percent of freshwater resources for agricultural and industrial consumption, mountains significantly contribute to food security and clean energy worldwide [4,5]. Mountains attract more than 50 million visitors per year and contribute to human and social capital required for the transition of the global green economy [1]. Given this discussion in the backdrop, we argue that mountains are, on the one hand, among one 
of the major drivers for the development of a global green economy and sustainable development. On the other hand, these drivers require an integration of socioeconomic and environmental concerns in decision-making process to foster sustainable development [6].

Despite their importance, however, mountains and sustainable mountain development have received little attention in international development agenda, and there are still significant constraints in the alleviation of mountain poverty, mitigation of environmental degradation and attainment of sustainable development $[7,8]$. On the one hand, mountain areas are prone to natural disasters like earthquakes, avalanches, floods, landslides, rock falls, glacial lake outbursts. While on the other hand, people living in these areas frequently face socioeconomic marginalization and their access to livelihood opportunities and basic services such as health and education is limited. While addressing an international conference on disaster risk reduction in Geneva, Switzerland (2011), Robert Glasser rightly said that "Poverty causes disasters and disasters cause poverty. "Poverty is both a driver and consequence of disasters, and the processes that further disasters risks related poverty are permeated with inequality" [9]. In this way, mountain communities face twin disaster risks simultaneously, i.e., natural disaster risks and socioeconomic disaster risks (economic poverty, multidimensional poverty and income inequality). These twin disaster risks, in return, push mountain people into a mountain poverty trap. Therefore, in the presence of these complex mountain characteristics, the objective of sustainable mountain development in mountain areas remained a major development concern for policy-makers and did not create the required results [10]. Poorly designed economic policies and mistargeted development programs that usually ignore the mountain specificities have failed to contribute to sustainable mountain development significantly $[8,11]$.

In Pakistan, the region under investigation by this study, almost $25 \%$ of the total population is living below the poverty line, while the population living in the rural mountains of Pakistan had the largest proportion of poverty head count, i.e., 34\% [8]. At the same time, the country is facing high unequal distribution of income as its Gini coefficient value has climbed up to $90 \%$ sharply, i.e., from 0.22 in 1960 to 0.42 in 2015 [12]. Compared to other geographic areas of Pakistan, poverty in mountainous areas has different roots. Challenges like dearth of access to factors and product markets make cultivation and agriculture very tough and this has led to a chronic poverty. Other sources of poverty include deterioration of the natural resource base, higher dependency rates, illiteracy, no or limited availability of health, education and financial services, gender-biased discernment and vulnerability to environmental degradation [13].

For reducing human vulnerabilities across the globe, research shows that inclusive finance is the most critical element. Financial inclusion, also called inclusive finance, refers to the delivery and accessibility of formal banking services such as credit, saving and insurance at an affordable cost to all low-income and disadvantaged individuals and businesses, irrespective of their personal net worth and company size [14,15]. For this particular research, microcredit was used as a proxy of financial inclusion.

Strong and handy financial connections among local entrepreneurs, public and private financial institutions are mandatory for sustainable mountain development [16]. Different studies suggest that the financial inclusion leads to sustainable social economic and environmental development [17]. Likewise, inclusive finance has been suggested as the most critical element that increases the income of poor families inclusively [18], having the ability to increase slum-dwellers' coping capacity in times of frequent disasters [19].

The inclusive finance or microfinance sector in Pakistan has been working for three to four decades. Keeping in view the poor to the population ratio, this industry in Pakistan has a vast scope. The industry reached out to 5.8 million active borrowers with a gross loan portfolio of PKR 202 billion; savings increased to PKR 186.9 billion with 30.9 million active savers [20].

In the Karakoram mountainous region of Pakistan, the microfinance sector evolved in 1993. Currently, two microfinance banks, namely, "The First Micro Finance Bank (FMFB)" and "Karakoram Cooperative Bank Limited (KCBL)," provide small amounts of inclusive finance/microcredit loans 
ranging from 10,000 PKR to 1,000,000 PKR on daily, monthly, half-yearly and yearly instalments to the poor and marginalized segment of the mountain society in the study area. PKR is the "currency symbol for Pakistani rupee". There are few empirical studies like $[21,22]$ that have confirmed the positive sides of the inclusive finance program in this area, but these studies were carried out in urban areas (mostly in Gilgit city and surroundings), completely ignoring rural mountainous areas of the Karakoram region. Secondly, poverty measurements discussed in inclusive finance literature in Pakistan are based on economic poverty, i.e., lack of money to afford basic human needs like food, clothing and shelter [23], and to assess this type of poverty, an absolute poverty line that "distinguishes the income and expenditure between poor and non-poor" was used. No doubt, money or income is an essential indicator of poverty but unproductive to measure poverty, because only one indicator (income) cannot represent the multifaceted face of poverty which "encompasses various deprivations experienced by poor people in their daily lives e.g., poor health, lack of education, inadequate living standards, disempowerment, poor quality of work and living in areas that are environmentally hazardous" [24]. Poverty is a multidimensional concept that encompasses various socioeconomic political and environmental deprivations faced by poor people in their daily lives; therefore, it is considered a superior and richer method to measure poverty than the traditional unidimensional approach [24-27].

Although "inclusive finance" has been used as a tool for poverty reduction in the mountainous regions of Pakistan, as discussed in the preceding paragraph, the dearth of academic literature examining the relationship between inclusive finance and poverty reduction poses challenges to evaluate the viability of "inclusive finance" as a tool of multidimensional poverty alleviation. Therefore, the questions that this research examined are: does financial inclusion help to improve mountain people's living standards and reduce multidimensional poverty and whether participation of the poor in inclusive finance programs contributes to sustainable mountain development in the Karakoram valleys of Pakistan? The region is so isolated that there exist no data on poverty estimates and other development indicators; therefore, a field survey was conducted to collect data, which itself is a valued addition to the researchers in the region. Unavailability of the baseline data about socioeconomic indicators was a hiccup in applying the difference-in-difference method, which is considered a superior method by [28]. In order to counter this limitation, the study relied on primary data collected by the researchers themselves in the study area and applied the Quasi-Experimental Designs (Post-tests with Experimental and Control Groups) method to explore the impact of inclusive finance on mountain inhabitants' living standards. The second limitation was the non-availability of female entrepreneurial data. The reason was that female entrepreneurs were limited in numbers and researchers could not contact them because of strict tribal traditions.

This study makes three major contributions: first, it does not rely on the conventional tools of poverty alone and examines the relationship between multidimensional poverty and inclusive finance. Second, the study makes a comparative analysis through the categorization of mountain poverty into economic and multidimensional poverty contexts to analyze the exact role of inclusive finance on their reduction. Third, despite ample evidence of higher socioeconomic and environmental vulnerabilities in mountainous areas, the majority of the inclusive finance programs and studies were carried out in plain areas of Pakistan, ignoring remote mountainous parts of the country; therefore, this study is also novel in the assessment of mountain-specific poverty in Pakistan.

The remainder of this paper is structured as follows: Section 2 focuses on research methodology and data collection under the heading "Materials and Methods". Results are presented in Section 3. Section 4 contains discussions. The last part of this study provides conclusions, future recommendations and implications of this research.

\section{Materials and Methods}

The following figure depicts the methodological procedure adopted in this study. 
We employed a mixed-method approach (Figure 1) to achieve the research objectives, e.g., to investigate the impact of financial inclusion on mountain community living standards, this study used the Quasi-Experimental Designs (Post-tests with Experimental and Control Groups) method. To analyse the impact of financial inclusion on economic and multidimensional poverty, Foster, Greer and Thorbecke measures of poverty and the Global Multidimensional Poverty Index methodology developed by Sabina Alkire were adopted, respectively. To capture income inequality among treatment and control groups, the Gini Index and Quintile technique were used. To determine major drivers of economic and multidimensional poverty in the study area, this study adopted the Binary Logistic Regression technique. The target population for this study consisted of the Microfinance Institutions (MFIs) operating in the Karakoram mountainous region of Pakistan as well as the inclusive finance beneficiaries of these MFIs. As far as survey design and sampling technique are concerned, we surveyed 424 households (212 each from beneficiary and non-beneficiary households of inclusive finance) through structured questionnaires using multistage sampling technique. Sample size was determined using Yamme sampling determination formula. The detailed description of the abovementioned methodological procedure is given below.

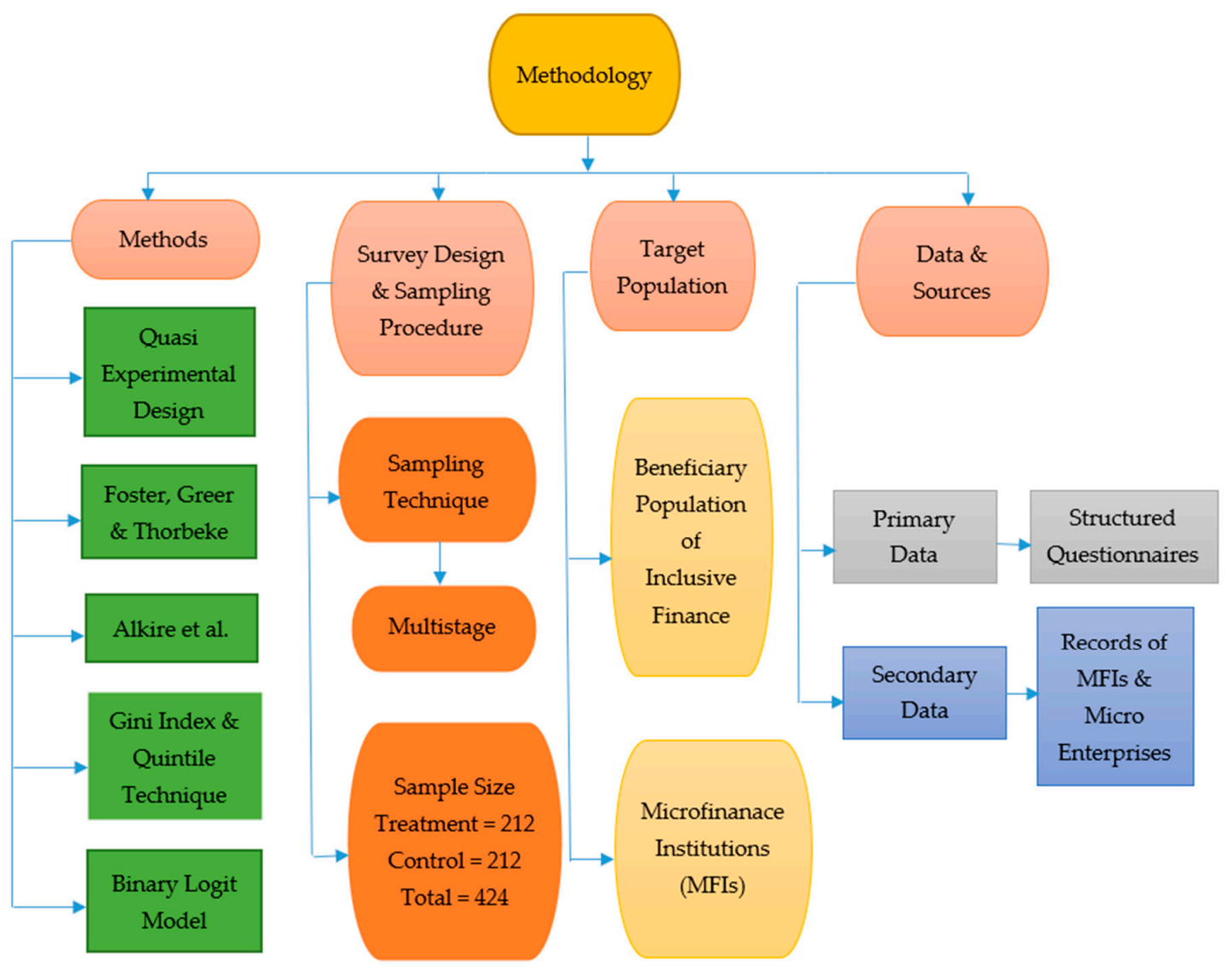

Figure 1. Methodological Procedure.

\subsection{Quasi-Experimental Designs}

For empirical investigation of the inclusive finance on mountain people's living standards i.e., income, expenditure and net worth, the present study adopted the Quasi-Experimental Designs (Post-tests with Experimental and Control Groups) method. This method was also used by $[21,29,30]$ in similar types of impact evaluation studies. This method measures the mean differences in a particular variable of interest among treatment and control groups due to participation in a specific program 
like an inclusive finance/microcredit program. The mathematical equation to show such kind of a relationship is given as follows:

$$
\Delta \bar{X}=\left(\overline{X_{T}}-\bar{X}_{c}\right)
$$

where:

$\Delta \bar{X}=$ Mean variation in the outcome variable

$\overline{X_{T}}=$ Mean variation in treatment outcome indicator

$\bar{X}_{c}=$ Mean variation in Control outcome indicator

$\mathrm{T}=$ Treatment households

$\mathrm{C}=$ Control households.

To avoid selection biases, various statistical and econometric technique are available in the impact evaluation literature. The study adopted the Poverty Score Card (PSC) acknowledged by the World Bank to match control and treatment groups in order to avoid selection biases. This method has been previously adopted by $[21,22]$ in similar types of inclusive finance impact evaluation studies in Pakistan. PSC is considered the most reliable method, because it controls observable selection biases. Compared to other methods, the poverty scorecard can be implanted quickly and cheaply $[28,29]$.

\subsection{Assessment of Absolute Poverty}

The method of absolute poverty investigates poverty by incorporating income or consumption deprivations [30]. Absolute poverty line is simply a minimum socially acceptable level of consumption or income required to make a distinction between the poor and non-poor population [31,32]. Through this method, policy-makers monitor changes across different subgroups of the population [33]. The official poverty line income of Pakistan for the year 2015-16 is PKR 3250.28 per adult equivalent per month. This poverty line income is available in the National Poverty Report of Pakistan [34] published by the Ministry of Planning Development and Reforms. In order to analyze incidence of absolute poverty in the study area, the present study adjusted inflationary changes over time on the basis of consumer price index (CPI) values, i.e., 4.2 for the year 2016-2017 and 3.9 for the year 2017-2018. CPI values are available in the Pakistan Economic Survey [35]. On the basis of CPI-adjusted values of income, we calculated poverty line income PKR 3518.87 per adult equivalent per month for the year 2017-2018, to do further analysis of economic poverty in the study area.

\subsubsection{Calculation of Incidence of Economic Poverty}

Incidence of economic poverty, also known as headcount of the economic poor, is the proportion of those living below the national poverty line in the total population $[13,28,36]$. It shows the number of poor people living in a society. The headcount of the economic poor can be calculated as:

$$
\gamma=\frac{c}{d}
$$

$\gamma=$ Headcount of economic poor

$c=$ Number of the economic poor (with income below the poverty line)

$d=$ Total mountain population (poor + non-poor).

The value of headcount index lies between 0 and 100 or 0 and 1 , where 0 represents that no one in the population is poor, while 100 or 1 represents that the whole population is poor.

\subsubsection{Intensity of Economic Poverty}

Intensity of economic poverty, also called poverty gap ratio, is the sum of income gap ratios of the population living below the poverty line divided by the poor population. It is an index of the 
income transfer required to get every poor person out of poverty [13,31,36-38]. It is measured using the formula given in Equation (3) as follows:

$$
\theta=\frac{1}{n} \Sigma\left[\frac{z-y_{i}}{z}\right]
$$

$\theta=$ Intensity of economic poverty

$\mathrm{z}=$ Poverty line income

$\mathrm{y}_{\mathrm{i}}=$ Income of each economic poor

$\mathrm{n}=$ Total population of economic poor

The value of this index also lies between 0 and 1 , where 0 represents that no one in the population is living below the poverty line; therefore, no income transfer is required, while 1 represents that the whole population is poor and $100 \%$ of the poverty line income is required to escape every poor out of poverty.

\subsubsection{Severity of Economic Poverty}

One of the major limitation of the poverty gap index is that it ignores income inequality among the poor. The poverty gap index treats all poor equally and proposes an equal income transfer for each poor to get him/her out of poverty. Severity of poverty undertakes income distribution among the economic poor, which can be measured by the squared proportionate poverty gap ratio [13,31,36-38]. It is simply a weighted sum of poverty gaps and gives more weight to those observations which fall well below the poverty line. The mathematical equation to measure severity of economic poverty is given as follows:

$$
\delta=\frac{1}{\mathrm{n}} \Sigma\left[\left(\frac{z-y_{1}}{z}\right)^{2}+\left(\frac{z-y_{2}}{z}\right)^{2}+\left(\frac{z-y_{3}}{z}\right)^{2}+\ldots+\left(\frac{z-y_{q}}{z}\right)^{2}\right]
$$

$\delta=$ Severity of economic poverty

$z=$ Poverty line income

$y_{1}$ to $y_{q}=$ Income of the poor

$n=$ Total population of the poor.

\subsection{Measurement of Multidimensional Poverty}

To measure multidimensional poverty in the study area, this study used the methodology developed by [24], following Sen's Capability Approach [39], after making necessary adjustments among dimensions and indicators of multidimensional poverty (for details, please see Table 1). This methodology has two major steps: an identification method that identifies who is poor among the total population by considering a range of deprivation they suffer and an aggregation method which constructs a numerical measure of poverty giving the ratio of poor in the population that can be broken down to target the poorest people and dimensions in which they are most deprived 
Table 1. Dimensions, weights, indicators and cutoff points.

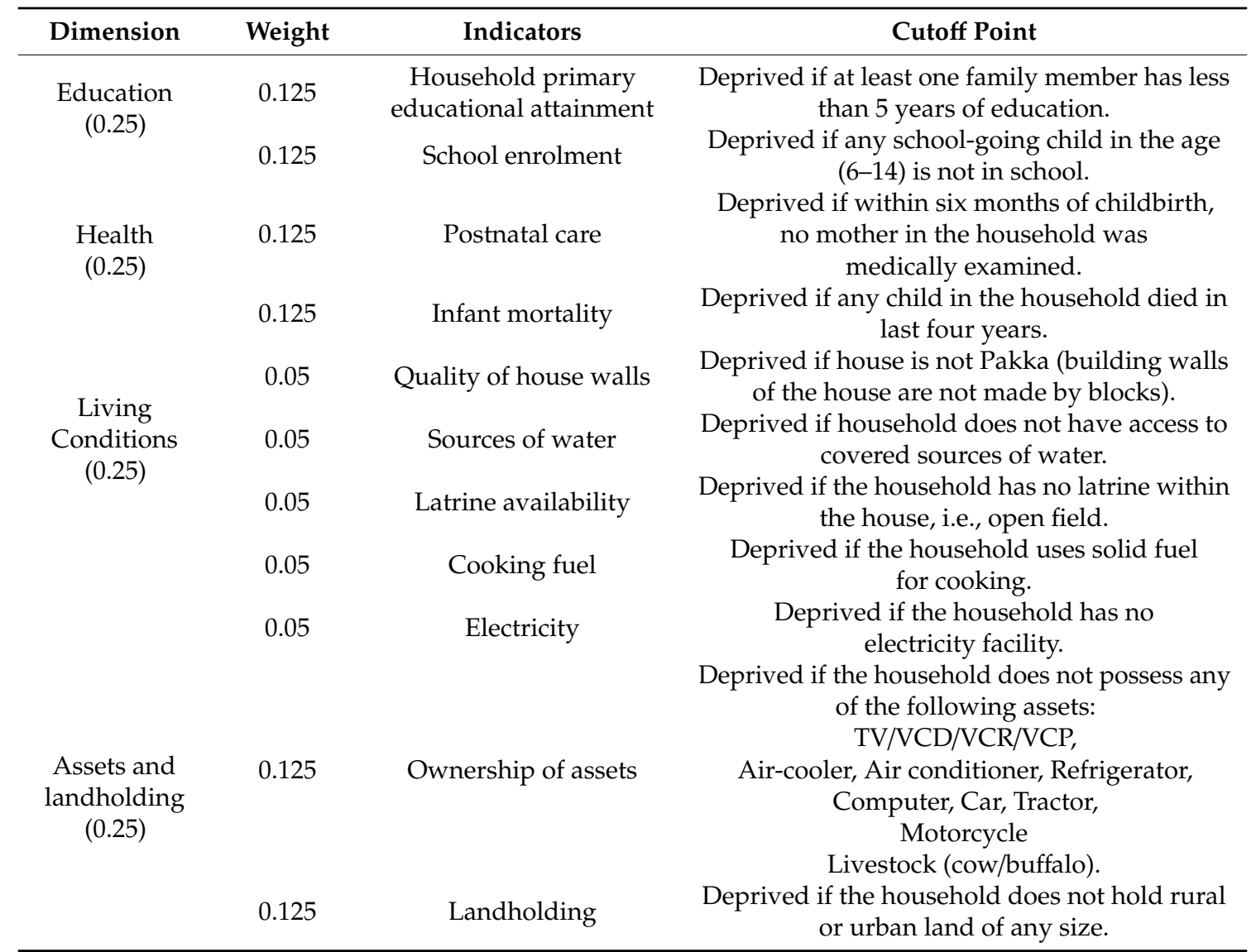

Source: [24]. Authors made necessary adjustments after detailed discussions with the government and nongovernment organizations officials, academicians and relevant field experts in the study area.

\subsubsection{Identification of the Poor}

Alkire et al. [24] proposed a different approach to measure multidimensional poverty that sets an aggregate deprivation threshold point $(\mathrm{k})$ for the identification of poor. Any subgroup among the population having higher deprivation compared to this threshold $(k)$ is considered multidimensional poor.

\subsubsection{Aggregation}

The next step after identification of poor is the aggregation. In this step, incidence, intensity, severity and vulnerability of multidimensional poverty along with the multidimensional poverty index are calculated. Details are given below.

\section{Incidence of Multidimensional Poverty}

Incidence of multidimensional poverty is "the percentage of population living below the multidimensional poverty line" and can be calculated as follows:

$$
\mathrm{H}=\frac{\mathrm{q}}{\mathrm{n}}
$$

where (q) shows the poor population and (n) shows the total population. 
Intensity of Multidimensional Poverty

The intensity of multidimensional poverty accounts the intensity or strength of average weighted deprivations of multidimensional poor. To measure intensity of multidimensional poverty, only the deprivations scores are summed and divided by the total number of multidimensionally poor people as below:

$$
\mathrm{A}=\frac{\sum_{I}^{q} C_{i}}{q}
$$

"A is the proportion of all possible dimensions (d) where multidimensional poor is deprived." $C_{i}$ is the deprivation score that $\mathrm{i}^{\text {th }}$ multidimensionally poor person experiences, while $q$ shows population of the poor.

\section{Multidimensional Poverty Index}

The intensity of multidimensional poverty does not provide enough information, i.e., how many people in a given population are multidimensionally poor. In order to bridge this gap, [24] method introduced another measure called "Multidimensional Poverty Index (MPI) which is the product of incidence $(\mathrm{H})$ and intensity of multidimensional poverty $(\mathrm{A})$ ".

$$
\mathrm{MPI}=\mathrm{H} \times \mathrm{A}
$$

\section{Severity of Multidimensional Poverty}

To find the severity of multidimensional poverty, this method introduced another aggregate cutoff point higher than the poverty line (k). In general, households/individuals faced with more than or equal to forty percent on the weighted sum of deprivation are considered as severe poor.

Vulnerability of Multidimensional Poverty

The vulnerability of multidimensional poverty relates to those people who are declared as non-poor, but their deprivation level is closer to the poverty line. A minor increase in their deprivation levels can thrust them below the poverty threshold. This study proposed deprivation scores ranging from 24 to 32 percent to declare any household as vulnerable.

Dimensions, Iindicators and Cutoff Points

The choice of dimensions and indicators to measure multidimensional poverty vary from country to country and from area to area, reflecting a particular study area context and socioeconomic, political and environmental priorities. Therefore, to build dimensions, indicators and cutoff points, this study followed guidelines provided in Alkire et al.'s [24] approach and made necessary adjustments (dropping or adding of indicators and adjustments of weights and cutoff points) after comprehensive discussions and consultations with government and nongovernment organizations' officials, academicians and experts in the field to capture true picture of multidimensional poverty in the Karakoram valleys of Pakistan. Our study included all the three core dimensions of the Global Multidimensional Poverty Index (MPI), i.e., education, health and living standards. However, the living standard dimension has further been categorized into two subdimensions, i.e., living conditions and asset and land holdings. The reason was that in mountainous areas, productive assets, i.e., land holdings and livestock, are the key assets to move any person/household out of poverty. Finally, a total of four dimensions (education, health, living conditions, assets and landholdings) and eleven indicators were built for the assessment of multidimensional poverty in the study area. Some of the indicators in the study are designed to understand and emphasize the gender component of poverty, i.e., household primary educational attainment, school enrolment, postnatal care because females in mountainous areas are considered as a marginalized gender of the mountain society. It is important to note that the school enrollment indicator supports gender equality since, if a boy or a girl is out of school, the household is deprived. This is 
even more of an emphasis in the year of school variable, which also captures gender disadvantages in education. The study assigned equal weights $1 / 4$ or 0.25 for each of the four core dimensions, i.e., education, health, living conditions and assets and land holdings. Within each dimension, all indicators were assigned equal weights. Table 1 given below provides details about dimensions, weights, indicators and cutoff points to measure multidimensional poverty in the Karakoram valleys of Pakistan.

\section{Unit of Analysis}

The unit of analysis to measure multidimensional poverty for this particular study is the "household".

\section{Poverty Threshold}

Alkire et al. [24] used one-third of the weighted sum of deprivations as the multidimensional poverty threshold for analysis. It entails that any household facing greater than 33.33 percent weighted sum of deprivations in all dimensions is considered as multidimensional poor. Our study also used the same threshold.

For the analysis of severity and vulnerability of multidimensional poverty, this study used threshold levels identified in the multidimensional poverty report of Pakistan (2016) released by "The Ministry of Planning, Development \& Reforms" in collaboration with the "Oxford Poverty \& Human Development Initiative (OPHI)" and the "United Nations Development Program (UNDP)". Any household scores more than or equal to 40 percent deprivation score in the weighted sum of all dimensions will be considered as severe poor, while any household facing deprivation scores ranging from 24 to 32 percent will be considered as vulnerable.

\subsection{Measurement of Income Inequality}

The term "Income inequality" refers to unequal distribution of income, among different sections or groups of the society [40]. To measure income inequality among treatment and control groups, we used the Gini Index along with Quantile Analysis. The Gini Index is a widely used measure of income inequality; therefore, it is favored over other alternatives, because this index can be applied to both time series and cross-sectional data simultaneously [41,42]. The value of the Gini Index ranges from 0 to 1 . With the value 1, the Gini coefficient represents perfect unequal distribution of income in the society, while with the value 0 , it represents perfect equality of income [40].

\subsection{Determinants of Socioeconomic Disasters (The Logit Model)}

The present study employed the Binary Logistic Model [43-46] to investigate the effect of socioeconomic variables including financial inclusion on socioeconomic disaster risks (economic poverty and multidimensional poverty) in the study area. The binary logistic regression model is presented below:

$$
\operatorname{Logit}\left(P_{i}\right)=\ln \frac{P_{i}}{1-P_{i}}=\beta_{0}+\sum_{j=1}^{k} \beta_{i} X_{i j}+\mu_{i}
$$

Equation (8) is the logistic regression equation and $\left(\frac{P_{i}}{1-P_{i}}\right)$ denotes odds ratio.

$P_{\mathrm{i}}=$ Poverty Status (1 poor, 0 otherwise, i.e., nonpoor)

$\beta_{0}=$ Intercept Parameter

$\beta_{\mathrm{i}}=$ Vector of regression coefficents

$X_{\mathrm{ij}}=$ Vector of predictors

$\mu_{\mathrm{i}}=$ Error $/$ residual term

The major characteristic of a logistic distribution is that when logit $(P)$ tends to the negative infinity, then $(p)$ tends to zero, and when logit $(P)$ tends to infinity, then $(p)$ tends to one [43]. There exists a 
nonlinear relationship between regressor and regressand in the logistic regression model; therefore, this model assumes nothing regarding the distribution of independent variables.

\subsection{Sampling Procedure}

\subsubsection{Population and Sample Size}

The target population for this study consisted of the microfinance institutions operating in the Karakoram valleys of Pakistan as well as the inclusive finance beneficiaries of these institutions. We used ArcGIS software (Esri, Redland, CA, USA) to show the study valleys in Figure 2 given as follows:

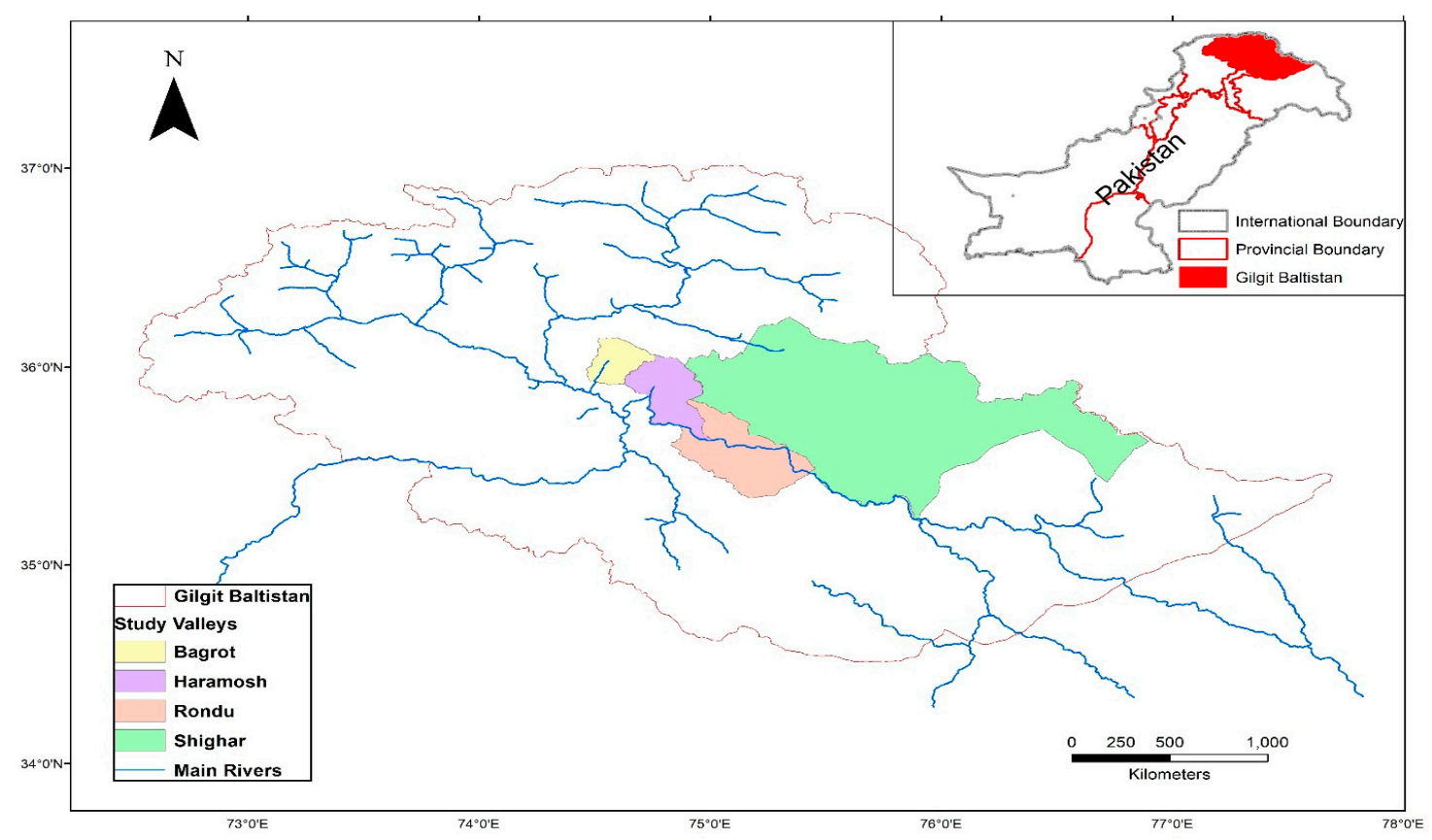

Figure 2. Map of Gilgit-Baltistan Showing study valleys.

\subsubsection{Sampling Technique}

The study followed a multistage sampling technique to avoid sampling variation in the study area. At the first stage, two districts from the Karakoram region of Pakistan were chosen randomly. At the second stage, two valleys from each district were chosen randomly. At the third stage, the sampling frame for the beneficiary households of inclusive finance for the year 2014 was collected from the microfinance banks operating in the study area. For the impact assessment of any development program or intervention, a minimum three-to-five-year period is required after its execution [21,31]; therefore, only those beneficiaries of inclusive finance were chosen for the treatment group who had joined the microfinance program in 2014 (five years before the survey year 2019). There were two microfinance banks in the Karakoram region of Pakistan in 2014 that provided the services of inclusive finance, i.e., the First Microfinance Bank (FMFB) and the Karakoram Co-operative Bank (KCBL). The sampling frame consisted of a valley-wise list of beneficiary households (treatment group).

At the fourth stage, to make our sample more representative, we selected beneficiary population (treatment group) from the two districts in each valley following Yamen's formula on random basis. Finally, equal numbers of sample from the control group were chosen following poverty scorecard of the treatment group. 


\subsubsection{Sample Size}

In order to determine a representative sample from the population, the study adopted [47] sample determination formula. According to him, assuming the maximum variability (which is equal to $50 \%)$, i.e., $\mathrm{p}=0.5$ and taking $95 \%$ confidence level with $5 \%$ precision level $(\mathrm{e}=0.05)$, the sample size should be:

$$
n=\frac{N}{1+N(e)^{2}}
$$

Population size and precision level are denoted by $(\mathrm{N})$ and $(\mathrm{e})$, respectively. Table 2 demonstrates the procedure of sample selection in the study area as follows:

Table 2. Calculation of Sample Size Through Yamane's Formula.

\begin{tabular}{|c|c|c|c|c|c|c|c|c|}
\hline Districts & Banks & Bagrote & Haramosh & Roundo & Shighar & $\begin{array}{c}\text { Total } \\
\text { (Treatment) }\end{array}$ & $\begin{array}{c}\text { Total } \\
\text { (Control) }\end{array}$ & $\begin{array}{c}\text { Grand } \\
\text { Total }\end{array}$ \\
\hline \multirow{3}{*}{ Gilgit } & KCBL & 27 & 23 & - & - & 50 & 50 & \\
\hline & FMFB & 25 & 28 & - & - & 53 & 53 & \\
\hline & Total & 52 & 51 & - & - & 103 & 103 & 206 \\
\hline \multirow{3}{*}{ Skardu } & KCBL & - & - & 19 & 24 & 43 & 43 & - \\
\hline & FMFB & - & - & 29 & 37 & 66 & 66 & - \\
\hline & Total & - & - & 48 & 61 & 109 & 109 & 218 \\
\hline \multicolumn{3}{|c|}{ Total Sample size (n) } & & & & 212 & 212 & 424 \\
\hline
\end{tabular}

Using Yamane's sample determination formula, a total of 212 samples of the treatment group for the four valleys in the two districts of the Karakoram region, who joined the inclusive finance program in the year 2014, were chosen. The respondents were enjoying different socioeconomic and demographic characteristics like married, unmarried, educated, uneducated, different age levels and assets holdings; therefore, we chose samples in the control group keeping in view the socioeconomic and demographic characteristic of the treatment group to minimize sample selection bias through the application of the Poverty Score Card (PSC) of the treatment group. Keeping in view the PSC of the treatment group, an equal number of samples for the control group from the same four valleys in both districts was selected. In this way, a sample size of (424) households was chosen for final analysis.

\subsubsection{Data Collection and Sources of Data}

Both primary and secondary data were used in this study. Primary data were collected through a structured questionnaire, administered by the researchers themselves in the study area in the year 2019. The questionnaire contained a combination of closed and open-ended questions designed to seek information about personal, socioeconomic and demographic variables of the respondents. The questionnaire employed for the collection of primary data was pilot-tested before the execution of the main study and was found reliable. The majority of the respondents were household heads in both the groups. Secondary data were obtained from the records of those microfinance banks surveyed as well as the records of the micro-businesses being studied. Other sources of secondary data included relevant government publications, textbooks and publications of the Pakistan Microfinance Network. The core unit of analysis for this particular study is household. However, per-capita-level analysis was also carried out where necessary. 


\section{Results}

\subsection{Descriptive Analysis}

Demographic characteristics of treatment and control group respondents including total population, male and female population, household size, gender, age, literacy level, marital status, relationship with the household head and occupation are presented in Table 3.

Table 3. Respondents' Profile.

\begin{tabular}{|c|c|c|c|}
\hline & \multicolumn{3}{|c|}{ Respondents } \\
\hline & Treatment Group & Control Group & All Respondents \\
\hline No. of Households & 212 & 212 & 424 \\
\hline Total Population & 1440 & 1489 & 2929 \\
\hline Male Population & 728 & 739 & 1467 \\
\hline Female Population & 712 & 750 & 1462 \\
\hline Household Size & 6.79 & 7.02 & 6.91 \\
\hline \multicolumn{4}{|l|}{ Gender } \\
\hline Male & $100^{1}$ & 100 & 100 \\
\hline \multicolumn{4}{|l|}{ Female } \\
\hline \multicolumn{4}{|l|}{ Age } \\
\hline Average Age & 34 & 33 & 33.5 \\
\hline Total Number of Respondents & 212 & 212 & 424 \\
\hline \multicolumn{4}{|l|}{ Age Group (\%) } \\
\hline $18-30$ & 33 & 35 & 34.0 \\
\hline $31-55$ & 67 & 65 & 66.0 \\
\hline Above 55 & - & - & - \\
\hline \multicolumn{4}{|l|}{ Literacy Level (\%) } \\
\hline Not Literate & 4 & 6 & 5 \\
\hline Primary & 19 & 20 & 19.5 \\
\hline Middle & 13 & 12 & 12.5 \\
\hline Secondary & 20 & 35 & 27.5 \\
\hline Higher Secondary & 24 & 11 & 17.5 \\
\hline Graduation & 8 & 11 & 9.5 \\
\hline Masters & 3 & 4 & 3.5 \\
\hline Others & - & - & - \\
\hline \multicolumn{4}{|l|}{ Maritaltatus (\%) } \\
\hline Never Married & 10 & 7 & 8.5 \\
\hline Married & 90 & 93 & 91.5 \\
\hline Divorced/Separated & - & - & - \\
\hline Widowed & - & - & - \\
\hline \multicolumn{4}{|l|}{ Relationship with HH Head (\%) } \\
\hline Self & 75 & 78 & 76.5 \\
\hline Son & 22 & 20 & 21.0 \\
\hline Brothers & 3 & 2 & 2.5 \\
\hline \multicolumn{4}{|l|}{ Occupation } \\
\hline Own Farming & 35.4 & 29.2 & 32.3 \\
\hline Off-Farm Skilled Labor & 37.7 & 29.2 & 33.5 \\
\hline Off-Farm Unskilled Skilled Labor & 5.2 & 25.9 & 15.6 \\
\hline Govt. Job & - & - & - \\
\hline Private Job & - & 8.5 & 4.2 \\
\hline Business & 21.7 & 7.1 & 14.4 \\
\hline Other Work & - & - & - \\
\hline Unemployed & - & - & - \\
\hline Old/Disabled & - & - & - \\
\hline
\end{tabular}


Table 3. Cont.

\begin{tabular}{|c|c|c|c|}
\hline & \multicolumn{3}{|c|}{ Respondents } \\
\hline & Treatment Group & Control Group & All Respondents \\
\hline $\begin{array}{c}\mathrm{N}=424 \\
\text { Treatment }=212 \\
\text { Control }=212\end{array}$ & & & \\
\hline
\end{tabular}

Note: ${ }^{1}$ Due to limited female financial inclusion in the Karakorum valleys of Pakistan, this research investigated male respondents only. Source. Authors' illustrations from survey data.

The total number of respondents were 424 (212 for each group) with 100 percent response rate. The survey results showed a relatively middle-aged population of respondents for both the control and treatment groups. In our study, all the respondents were male. As mentioned in the limitations of the study, female access to the inclusive finance program in the study area was restricted due to strict tribal traditions; therefore, the numbers of female-owned enterprises were limited and researchers collected data from the owners of male-owned enterprises only. The average age for the sample treatment group respondents was 34 years, while for the control group it was 33 years. For the treatment group, $33 \%$ of the respondents were in the age range of $18-30$ years and $67 \%$ of respondents were aged between $31-55$ years. For treatment group $35 \%$ of respondents were in the age range of $18-30$ years, and $65 \%$ of the respondents fell in the age bracket of 31-55 years. No respondent was found above 55 years of age in both the treatment and control groups. The marital status of the respondents showed that $10 \%$ of respondents in the treatment group were never married, while $90 \%$ of respondents were married. Marital status statistics for the control group showed that $7 \%$ of respondents were never married while $93 \%$ were married. No respondent was found in the divorced and widowed category of marital status in both groups. Literacy data presented in Table 3 showed that a higher proportion (6\%) of control group respondents as compared to (4\%) treatment group respondents were illiterate. Among the literate respondents of the treatment group, $19 \%$ completed a primary level of education, $13 \%$ of respondents attended middle level, $20 \%$ of the respondents completed matric level, $24 \%$ completed higher secondary, $8 \%$ completed graduation and rest of them, i.e., $3 \%$ of respondents, completed a master level of education. The literacy statistics of control group respondents revealed that $20 \%$ of respondents completed a primary level of education, $12 \%$ attended middle, $35 \%$ completed matric and the remaining $26 \%$ of the respondents completed a post-matric level of education.

The demographic structure for 212 treatment group households showed a population of 1440 household members with 728 (50.56\%) male and $712(49.44 \%)$ female members. Similarly, for 212 control group households, the total population was 1489 persons with 739 (49.63\%) male and $750(50.37 \%)$ female household members. The mean household size for the treatment group was 6.79 members, which is slightly lower than the control group household size of 7.02 members. Off-farm skilled labor is the major profession for treatment respondents, as $37.7 \%$ of respondents were associated to this profession followed by own farming $35.4 \%$ and business $21 \%$, respectively, while in the control group, the majority of the respondents $(29.2 \%)$ were engaged in the profession of own farming followed by $29.2 \%$ off-farm unskilled labor, and only $7.1 \%$ of respondents were engaged in business profession. The higher engagement of treatment group respondents with off-farm activities like off-farm skilled labor and business as compared to control group respondents further acknowledged the positive role of inclusive finance on enterprise development and employment generation in the study area.

\subsubsection{Major Sources of Treatment and Control Groups Income}

The results of Figure 3 given below portray that labor is the major source of treatment income, contributing $(34.19 \%)$ for the treatment income followed by business $(21.94 \%)$ and crops $(21.67 \%)$, respectively. Other treatment income sources were livestock, services, pension, rental income, remittances and cash gifts, etc. With the income share of $(42.83 \%)$, labor is the single largest source of control group income, followed by crops (20.6\%) and services (10.03\%). Only $7.90 \%$ of the control group 
income was generated from business source. The higher income share of the treatment group in crops and business sources is an indication of positive program impact, because microfinance institutions in the study area concentrated on micro entrepreneurs and small farmers to get them out of poverty.

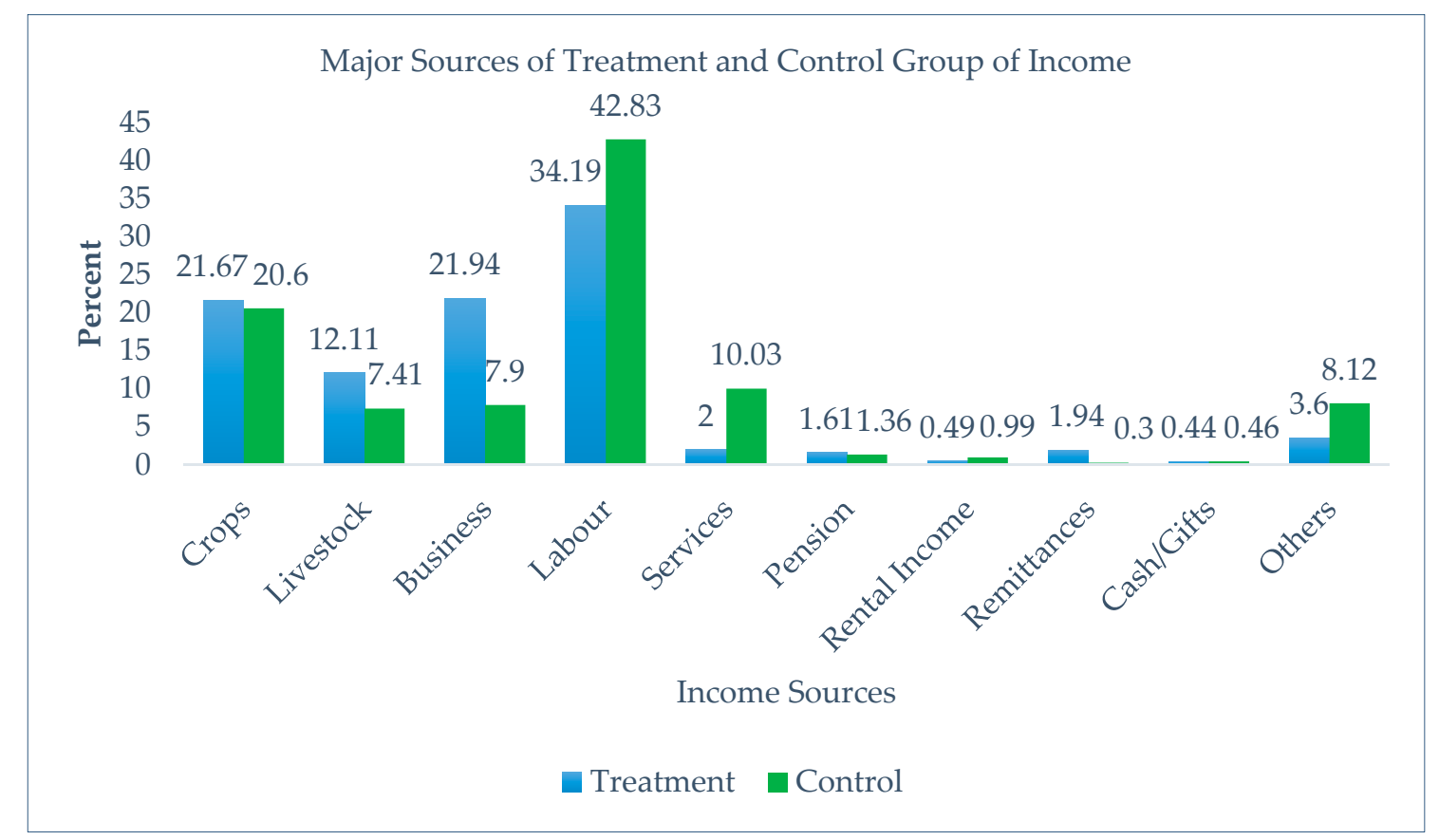

Figure 3. Major Sources of Treatment and Control Groups Income in the Karakoram valleys of Pakistan;

Source: Graphic derived from survey data by authors.

\subsubsection{Expenditure Patterns of Treatment and Control Groups}

The expenditure patterns of treatment group households showed that $39.19 \%$ of expenditures were made on food consumption, $14.51 \%$ on housing, $14.39 \%$ on education, $11.88 \%$ on clothing, $7.95 \%$ on health care, $4.47 \%$ on fuel, $2.53 \%$ on transport and rest of them on other purposes. The expenditure patterns of control group households in the study area were: $36.84 \%$ of expenditures were made on food, $22.12 \%$ on housing, $12.64 \%$ on education, $11.34 \%$ on clothing, $7.54 \%$ on health care, $3.52 \%$ on fuel, $1.52 \%$ on transport and the rest of them were made on other purposes.

Expenditure patterns also showed that treatment households spent higher amounts of income on education, which showed treatment group awareness regarding quality of education in the study area. Similarly, higher fuel and transport expenditures from the treatment side indicated the growth of business activities and enterprise development in the study area, which is necessary for employment generation and sustainable mountain development.

\subsubsection{Use of Credit by Treatment Group in the Karakoram Valleys of Pakistan}

The study results showed that the majority of the inclusive finance/microcredit funds were invested by the treatment group on productive uses, i.e., $48.87 \%$ of funds were invested in business activities, $24.7 \%$ of the funds were used to build business fixed investment and $14.01 \%$ of funds were used to purchase farm inputs. The reward of this productive use of microcredit funds by the treatment group was reflected in the form of a higher income share of the treatment group in crops and business sources of income (see Figure 2). Research showed that proper monitoring of microcredit funds is necessary not only for the productive use of funds but also for the success of any microcredit/finance program [48]. 


\subsection{Impact of Inclusive Finance on Household Living Standards in the Karakoram Valleys of Pakistan}

The results of inclusive finance/microcredit loans provided by microfinance institutions on the mountain community's standards of living are presented in Table 4 below.

According to the results reported in Table 4, average annual household income, per-capita income and monthly per-capita income for the treatment group in the study area were PKR 331,331.56, PKR 52,687.35 and PKR 4390.64, respectively. Similarly, for the control group, these income values were PKR 312,916.33, PKR 47,457.27 and PKR 3954.76. Results also showed positive mean differences among the treatment and control groups for all the three categories of income. These positive mean differences for both groups were also evident in different categories of expenditures. Similarly, positive mean differences were also found for net worth at household and per-capita levels. These positive mean differences between treatment and control groups among different categories of living standards indicated that treatment households were economically better off than control group households in the study area; therefore, we argue that improvement in treatment group households living standards is due to their participation in the inclusive finance program. These results were also in line with some previous studies, e.g., [21,49].

In order to check whether mean differences among different categories of living standards for control and treatment groups in the study area were significant or not, the study employed an independent sample $t$-test. The independent sample $t$-test results showed that the difference between two means for both groups in two categories of living standards (income and expenditures) were significant, indicating a substantial positive impact of the microcredit program in the study area. However, the net worth category of living standards showed insignificant mean difference for the treatment and control groups, because asset building requires a longer time period than income generation. 
Table 4. Mean Distribution and Mean Differences of Income, Expenditures and Net Worth among Treatment and Control Groups.

\begin{tabular}{|c|c|c|c|c|c|c|}
\hline & \multicolumn{2}{|c|}{ Treatment Group } & \multicolumn{2}{|c|}{ Control Group } & \multirow[t]{2}{*}{ Mean Difference } & \multirow[t]{2}{*}{$\begin{array}{c}p \text {-Value } \\
(t \text {-Test) }\end{array}$} \\
\hline & Mean & Standard Deviation & Mean & Standard Deviation & & \\
\hline \multicolumn{7}{|l|}{ Income } \\
\hline Annual Household Income & 331,332 & 70,439 & 312,916 & 79,906 & 18,415 & $\begin{array}{c}2.52 \\
(0.012) * *\end{array}$ \\
\hline Per-Capita Income & 52,687 & 15,027 & 47,457 & 16,258 & 5230 & $\begin{array}{c}3.44 \\
(0.001)\end{array}$ \\
\hline Monthly Per-Capita Income & 4391 & 1252 & 3955 & 1355 & 436 & $\begin{array}{c}3.44 \\
(0.001) *\end{array}$ \\
\hline \multicolumn{7}{|l|}{ Expenditures } \\
\hline Annual Household Expenditures & 258,541 & 58,748 & 244,163 & 58,131 & 14,378 & $\begin{array}{c}2.53 \\
(0.012) * *\end{array}$ \\
\hline Per-Capita Expenditures & 41,339 & 13,289 & 37,010 & 12,317 & 4329 & $\begin{array}{c}3.48 \\
(0.001) *\end{array}$ \\
\hline Monthly Per-Capita Expenditures & 3445 & 1107 & 3084 & 1026 & 361 & $\begin{array}{c}3.48 \\
(0.001) *\end{array}$ \\
\hline \multicolumn{7}{|l|}{ Net Worth } \\
\hline Household Net worth & $1,415,380$ & 328,602 & $1,408,073$ & 307,676 & 7307 & $\begin{array}{c}0.24 \\
(0.81)\end{array}$ \\
\hline Per-Capita Net worth & 117,948 & 27,383 & 117,339 & 25,640 & 609 & $\begin{array}{c}0.24 \\
(0.813)\end{array}$ \\
\hline
\end{tabular}

Note. ${ }^{*} p<0.01,{ }^{* *} p<0.05$; Source. Authors calculations from survey data. 
3.3. Impact of Microcredit on Socioeconomic Disaster Risks (Economic Poverty, Multidimensional Poverty and Income Inequality)

Table 5 reported results of socioeconomic disaster risks, i.e., economic poverty, multidimensional poverty and income inequality in the study area

Table 5. Impact of Microcredit on Socioeconomic Disasters (Economic Poverty, Multidimensional Poverty and Income Inequality).

\begin{tabular}{|c|c|c|c|}
\hline & \multicolumn{3}{|c|}{ Respondents } \\
\hline & Treatment Group & Control Group & All Households \\
\hline \multicolumn{4}{|l|}{ Economic Poverty } \\
\hline Total Households & 212 & 212 & 424 \\
\hline Non-poor & 158 & 133 & 291 \\
\hline Poor & 54 & 79 & 133 \\
\hline Economic Poverty Headcount Ratio & 25.47 & 37.26 & 31.36 \\
\hline Poor Population (Headcount) & 54 & 79 & 133 \\
\hline Intensity of Economic Poverty & 9.88 & 19.77 & 29.65 \\
\hline Severity of Economic Poverty & 2.44 & 6.94 & 9.39 \\
\hline \multicolumn{4}{|l|}{ Multidimensional Poverty } \\
\hline Total Households & 212 & 212 & 424 \\
\hline Non-poor & 145 & 128 & 273 \\
\hline Poor & 67 & 84 & 151 \\
\hline Multidimensional Poverty Headcount Ratio & 31.60 & 39.62 & 35.61 \\
\hline Poor Population (Headcount) & 67 & 84 & 151 \\
\hline Intensity of Multidimensional Poverty & 41.04 & 42.68 & 41.95 \\
\hline Multidimensional Poverty Index (MPI) & 12.97 & 16.91 & 14.94 \\
\hline Severe poor & 47 & 70 & 117 \\
\hline Severity of Multidimensional Poverty & 22.17 & 33.02 & 27.59 \\
\hline Vulnerable & 58 & 53 & 111 \\
\hline Vulnerability of Multidimensional Poverty & 27.36 & 25.00 & 26.18 \\
\hline \multicolumn{4}{|l|}{ Income Inequality } \\
\hline $\begin{array}{c}\text { Gini Index } \\
\text { Quintile Analysis }\end{array}$ & 11.88 & 14.15 & 13.01 \\
\hline 1st Quintile (Lowest 20\%) & 14.57 & 13.25 & 14.02 \\
\hline 2nd Quintile & 17.23 & 17.05 & 17.42 \\
\hline 3rd Quintile & 19.20 & 19.33 & 19.59 \\
\hline 4th Quintile & 21.52 & 21.89 & 22.08 \\
\hline 5th Quintile (Highest 20\%) & 27.48 & 28.47 & 26.89 \\
\hline
\end{tabular}

Source: Authors' illustrations from survey data.

Headcount ratio is the proportion of the population living below the poverty threshold. According to the survey results depicted in Table 5, both economic and multidimensional poverty headcount ratios for the treatment group were less than the control group (e.g., $25.47<37.26$ and $31.60<39.62)$, showing the positive effect of financial inclusion in the study area. Along with poverty headcount ratio, the ratios of intensity and severity of economic and multidimensional poverty in the treatment group were also lower than the control, group which further acknowledged the positive effect of the inclusive finance program.

The value of the Gini Index lies between (0) and (1), e.g., [40], where (0) represents perfect equal distribution and (1) represents perfect unequal distribution of income among the society. The concentration value calculated through Gini-coefficient for the treatment group in Table 5 is 11.88, which is lower than the control group (14.15). It implied that income was fairly distributed among the treatment group population compared to the control group. Quintiles analysis showed that the lowest $(20 \%)$ of the treatment group population owned an income share of $14.57 \%$, while the same group of 
population in the control group owned a $13.25 \%$ income share. This showed a higher income share of relatively low income households in the treatment income and lower income inequality than control group households. Similarly, the highest (20\%) treatment group households owned $27.48 \%$ income share and the same group on control side occupied $28.47 \%$ income share. It implied that the slightly well-off class in the control group owned a larger income share than the treatment group. On the basis of the survey results, we argue that lower income inequality among treatment group households is because of their participation in the inclusive finance program.

\subsection{Determinants of Socioeconomic Disaster Risks (ML Estimation of Binary Logit Model)}

Table 6 given below highlights major determinants of socioeconomic disaster risks in the Karakoram Valleys of Pakistan.

Table 6. Determinants of Socioeconomic Disaster Risks (ML Estimation of Binary Logit Model).

\begin{tabular}{|c|c|c|c|c|c|}
\hline Variables & Coefficient & Standard Error & Wald Stat & $p$-Value & Odds Ratio \\
\hline \multicolumn{6}{|l|}{ Economic Poverty } \\
\hline Farm Land Ownership & -0.10 & 0.08 & 1.74 & 0.18 & 0.89 \\
\hline Dependency Ratio & $0.62 * *$ & 0.28 & 4.73 & 0.03 & 1.86 \\
\hline Female/Male Ratio & $-0.70^{* * *}$ & 0.39 & 3.26 & 0.07 & 0.49 \\
\hline Household Size & $0.71 *$ & 0.12 & 36.59 & 0.00 & 2.05 \\
\hline Financial Inclusion & $-0.87^{* *}$ & 0.39 & 5.16 & 0.02 & 0.42 \\
\hline OP Assets Index & $-0.27^{* *}$ & 0.13 & 4.11 & 0.04 & 0.76 \\
\hline Living Conditions Index & $-0.29 *$ & 0.08 & 14.48 & 0.00 & 0.75 \\
\hline Household Head Age & $-0.05^{*}$ & 0.02 & 7.54 & 0.00 & 0.94 \\
\hline $\begin{array}{l}\text { Household Head } \\
\text { Education }\end{array}$ & $-0.13^{* *}$ & 0.052 & 6.10 & 0.015 & 0.88 \\
\hline Postnatal Care & $-1.18^{* *}$ & 0.57 & 4.23 & 0.04 & 0.31 \\
\hline Constant & -0.12 & 1.44 & 0.00 & 0.93 & 0.89 \\
\hline Test/Summary & $x^{2}$ & df & $\mathbf{P}$ & $\mathrm{N}-\mathrm{R}^{2}$ & $C \& S-R^{2}$ \\
\hline Omnibus & 299.263 & 10 & 0.000 & 0.711 & 0.506 \\
\hline Hosmer \& Lemeshow & 6.024 & 8 & 0.645 & & \\
\hline \multicolumn{6}{|l|}{$\begin{array}{l}\text { Multidimensional } \\
\text { Poverty }\end{array}$} \\
\hline Dependency Ratio & $1.07 *$ & 0.31 & 11.98 & 0.00 & 2.91 \\
\hline Female/Male Ratio & 0.39 & 0.38 & 1.32 & 0.25 & 1.47 \\
\hline Household Size & $0.41 *$ & 0.11 & 13.22 & 0.00 & 1.50 \\
\hline Financial Inclusion & -0.53 & 0.36 & 2.15 & 0.14 & 0.59 \\
\hline Household Head Age & $-0.04^{* *}$ & 0.02 & 4.46 & 0.04 & 0.96 \\
\hline $\begin{array}{l}\text { Household Head } \\
\text { Education }\end{array}$ & $-0.53 *$ & 0.07 & 54.01 & 0.00 & 0.59 \\
\hline $\begin{array}{l}\text { Household Head } \\
\text { Occupation }\end{array}$ & $-0.86^{* *}$ & 0.37 & 5.28 & 0.02 & 0.42 \\
\hline Constant & 1.11 & 1.26 & 0.79 & 0.38 & 3.03 \\
\hline Test Summary & $x^{2}$ & df & $\mathbf{P}$ & $\mathrm{N}-\mathrm{R}^{2}$ & $C \& S-R^{2}$ \\
\hline Omnibus & 336.634 & 7 & 0.000 & 0.753 & 0.548 \\
\hline Hosmer \& Lemeshow & 6.575 & 8 & 0.583 & & \\
\hline
\end{tabular}

Note. ${ }^{*} p<0.01,^{* *} p<0.05,{ }^{* * *} p<0.1$; Source: Authors' illustrations from survey data.

The results of binary logistic regression in the economic poverty model indicated that higher dependency ratio and higher household size significantly contributed to the probability of economic poverty. On the other hand, higher level of household head education, age, financial inclusion through microcredit program, female-to-male ratio, other productive assets index, living condition index and postnatal care significantly contribute to the probability of being non-economic poor in the study area. 
Although, farmland ownership has a negative effect on household poverty status in the study area but it is insignificant even at $10 \%$ level of significance.

Binary logistic regression results of the multidimensional poverty model indicated that higher dependency ratio and higher household size contributed to the probability of being multidimensional poor. This result was the same as in the economic poverty model. On the other hand, higher levels of household head education, age and occupation significantly contributed to the probability of being non-multidimensionally poor. Although financial inclusion via a microcredit program reduced the probability of being non-multidimensionally poor, the coefficient of financial inclusion was insignificant even at $10 \%$ level of significance, indicating a negligible impact on multidimensional poverty. Similarly, higher female-to-male ratio contributed to the probability of being multidimensionally poor, as the coefficient of female-to-male ratio was positive but insignificant, which indicated a minor impact on multidimensional poverty status of the experimental group households in the Karakoram region of Pakistan.

\section{Discussion}

Studies suggest that the provision of improved livelihoods to mountain inhabitants will enable them to preserve natural resources and to play their role as mountain steward [50]. Inclusive finance has played an imperative role in reducing poverty and ensuring socioeconomic and environmental development across the world; therefore, it has been strongly recognized by the 2030 Development Agenda. Sustainable development requires that all human beings will have the opportunity to satisfy their basic needs, enjoy equal access to resources, and have a say in economic and social development process [17]. The development of sustainable finance leads to sustainable social economic and environmental development [51]. The inclusive finance sector is considered an important contributor to the expansion of formal financial systems and has played a significant role in sustainable development [52]. It is playing a leading role to achieve sustainable development by providing access to financial resources and by creating productive opportunities to poor and marginalized people who are usually excluded by conventional banking systems $[53,54]$. Through our research, we explored the relationship between inclusive finance, living standards, economic and multidimensional poverty, income inequality and sustainable development. We found positive and significant relationships among two major indictors of living standards, i.e., income and expenditures of the treatment group in the study area, while the third indicator of net worth (assets-liabilities) was also positive but insignificant (see Table 4). It implies that inclusive finance or microcredit program has positively contributed towards mountain community's living standards—an important ingredient for achieving Sustainable Development Goals (SDGs).

Results reported in Table 5 also showed reduced economic and multidimensional poverty headcounts, intensity and severity in the treatment group as compared to the control group, indicating the positive role of inclusive finance towards mountain poverty reduction and accomplishment of SDG 4 "Quality Education", SDG 3 "Good Health \& Wellbeing", SDG 2 "Zero Hunger and SDG 1 "Eradication of Extreme Poverty \& Hunger" in the Karakoram valleys of Pakistan. Along similar lines, lower income inequalities in treatment group than control group households were also observed, as evident from the results of Gini Index and quintile analysis (see Table 5). This reduction in income inequalities contributes to SDG 10 "Reduced Inequality".

The binary logistic regression results displayed in Table 6 indicated major determinants of economic and multidimensional poverty in the study area. Slope coefficients ( $\beta \mathrm{s}$ ) associated to independent variables in logistic regression model show the change in the logit corresponding to a unit change in independent variable. Similarly, in logistic regression technique, odds ratios are commonly used to measure the magnitude of any particular program or intervention effect [55]. Each variable in the logistic regression is individually evaluated by using the p-value of Wald test statistic. We saw some interesting results in the estimated logit model. First, the farmland ownership in the economic poverty model has a negative impact on economic poverty (odds ratio less than one) 
but it is insignificant even at $10 \%$ level of significance. It implies that having higher ownerships in mountain farmland does not contribute to economic poverty reduction in the study area. Due to geographical constraints, mountain farmers operate in a particularly demanding environment, i.e., the weather and soil conditions shorten the growing season, labor costs are higher and the topography makes the use of conventional machinery more difficult; therefore, productivity is on average lower in mountain areas than farming on the plains. Along similar lines, due to limited credit facilities and financial exclusion by the conventional commercial banking sector in mountainous areas, poor farmers often depend on informal money lenders. These money lenders charge heavy rates of interest and farmers have to sell their produce at a low price to these money lenders. The result is low productivity, and thus low income pushing mountain farmers to economic poverty.

Variables like dependency ratio and household size have odds ratios greater than one in both economic and multidimensional poverty models, which implies that both variables have a positive relationship with the probability of being mountain poor, i.e., an increase in household size and dependency ratio, the probability of being mountain poor also increases significantly. These results were also in line with other studies [13,56-58]. On the other hand, the female-male ratio showed some interesting results in both models. The coefficient of female-to-male ratio in economic poverty $(-0.70)$ is significant at $10 \%$ and has a negative sign. It means that as there is an increase in female-to-male ratio, the probability of being mountain poor decreases. This is because most of the women in the Karakoram region of Pakistan were actively playing their role as natural resource managers, i.e., they are farmers who plant and water the seeds, take care of the livestock, feed and milk the cows, and look after the households; therefore, we can say that more female members in the household have more chance to escape that household from economic poverty. Based on our findings, we argue that household composition can play an important role in the determination of household economic poverty status in mountainous regions. This result contradicts various studies like $[13,56]$ in Pakistan.

On the other hand, the same coefficient in multidimensional poverty model has a value of 0.39 , with a positive sign indicating that an increase in female-to-male ratio in the household increases the probability of being multidimensionally poor. Women in the Karakoram region are disadvantaged in various ways, i.e., they experience unequal treatment based on traditional gender relationships that deprive them from equal access to health, education, property, financial services and well-being. The socioeconomic disaster risks are higher for women than men as in most of the world's disasters, more females are affected than males [59]. Therefore, policy-makers must focus on gender equality and women empowerment through the provision of some basic services like education and health, along with women's inclusion in the microcredit program to achieve rapid and sustained mountain development. It is also necessary to reflect a true picture of mountain poverty by including both monetary and non-monetary indicators in the poverty assessment process, because only monetary indicators like income and consumption in mountain areas do not present the true estimates of mountain poverty.

Financial inclusion in the study area has significantly reduced the risk of being mountain economic poor. It means that any household member who participates in an inclusive finance program becomes an income-earning source for that particular household, thus reducing the risk to become trapped into economic poverty. These results also validate the results of some previous studies $[21,22]$ that suggested an inverse relationship between financial inclusion and economic poverty. The results of the multidimensional poverty model suggest that financial inclusion had a positive but insignificant impact on multidimensional poverty reduction in the study area. Although the coefficient has a negative sign, it is insignificant, showing a mild effect on multidimensional poverty. Since improvements in multidimensional poverty indicators need more time than the improvement in economic poverty indicator, i.e., income, we therefore argue that, in the long run, inclusive finance will also impact multidimensional poverty indicators significantly. Policy-makers implement strategies for promoting and creating greater access to financial inclusion programs as these have the capacity to reduce both 
economic and multidimensional poverty and have a greater role in sustainable mountain development accomplishment [60,61].

The Productive Assets (OP) Index, i.e., other than farmland like livestock, fruit and forest trees, machinery suggest a significant negative correlation with the chance of being economic poor. The population of livestock is one of the major sources of livelihood in the study area. Living conditions index (housing structure, water supply, electricity and cooking fuel) also reduced the risk of being economic poor. People having good living conditions, i.e., pukka house, piped water, access to electricity and liquid purified gas (LPG) as cooking fuel instead of solid cooking fuel like firewood, have significantly eliminated the chance of living in economic poverty in the Karakoram region of Pakistan. Likewise, the household head's education and age in the sample suggest a significant negative relationship with economic and multidimensional poverty. It implies that more educated and experienced household heads can manage resources efficiently, thus reducing the probability of being economic and multidimensional poor. More often, mothers are not medically examined during pregnancy in mountain areas either because of a lack of healthcare facilities or lack of financial resources and poor transportation facilities. Results suggest that medically examined (postnatal care) mothers have an inverse relationship with the economic poverty status in the study area. A healthy mother not only gives birth to healthy babies, reducing health expenditures on his/her baby's health, but also contributes to income-generating activities effectively. Therefore, the postnatal care variable shows a strong negative effect on economic poverty status.

People living in mountain areas have limited resources to satisfy their basic needs. The poverty data in Pakistan portray a miserable picture of poverty and income inequality, which induced the poor to commit crimes in the country [62]. The Karakoram region of Pakistan is a far-flung area and falls among one of the most remote regions of the country. The geo-economic and strategic placement of the region, i.e., the Hindu Kush and Karakoram Ranges of mountains in the north and western Himalayas in the south, possesses specific importance for the country. Not only this, the China-Pakistan Economic corridor (CPEC) also increased its strategic presence. The spectacular natural beauty and famous mountain peaks like $\mathrm{K} 2$, the second highest peak in the world, attract national and international tourists to come to this region every year, which contributes to economic growth of the country positively [63]. For sustainable development of the country in general and sustainable mountain development in particular, it is important to overcome socioeconomic disaster risks in mountain areas following the path of pro-poor growth that directs resources to those areas which are comparatively less developed.

\section{Conclusions and Recommendations}

This study was undertaken to analyze the impact of financial inclusion on mountain community living standards, reduction of economic and multidimensional poverty along with income inequality and sustainable mountain development in the Karakoram valleys of Pakistan. For empirical investigation, the study employed a mixed-method approach which involved a survey of 424 households (212 each from beneficiary and non-beneficiary households of inclusive finance) through structured questionnaires using a multistage sampling technique. Based on survey results, the study concluded that inclusive finance provided by FMFB and KCBL has successfully improved household income, expenditures and reduced economic vulnerabilities in the study area, as evident from the significant results of independent sample $t$-test for annual, per-capita and monthly per-capita income and expenditures (see Table 4 for details). The impact of microcredit on the third indicator of living standards, i.e., net worth, is also positive. Similarly, treatment households in the study area were less deprived in incidence, intensity and severity of both economic and multidimensional poverty and enjoyed lesser income inequalities than their counterparts (see Table 5 for results). The variable of financial inclusion for economic poverty in the logit-model showed a positive and significant result $(\beta=-0.87, p=0.02)$ indicating a remarkable impact of on economic poverty while the same variable in the multidimensional poverty model showed negative but insignificant result $(\beta=-0.53$, $p=0.14$ ) indicating a mild impact on multidimensional poverty. These conclusions strengthened 
the clue that financial inclusion of the poor through inclusive finance programs is the best strategy to manage socioeconomic disaster risks in mountainous areas to achieve the global objective of sustainable development.

The study suggests following recommendations for policymakers and other stakeholders to achieve sustainable mountain development in remote mountainous regions of Pakistan.

Like other mountainous areas, soil characteristics in the Karakoram region of Pakistan favor the production of fodder crops, fruit and forest trees; therefore, by developing agroforestry- based enterprises, particularly the development of non-timber-based forest products and agroforestrylivestock-based production with the help of "Green Microfinance" in the region can further reduce mountain community vulnerabilities by increasing their income levels. So microfinance institutions (MFIs) should encourage and invest in agroforestry non-timber-based microenterprises to enhance quality of life of mountain communities and to improve microclimate conditions in the region. Green Microfinance can tackle not only the problems of poverty and financial exclusion, but at the same time can manage environmental protection and energy crisis efficiently. Furthermore, the majority of the people living in the Karakoram region of Pakistan are dependent on the use of natural resources, which speeds up their depletion. Through Green Microfinance, we can reduce the depletion of these natural resources and minimize the destruction of climate change to achieve the global objective of sustainable development.

Gender equality is a prerequisite for integrated and sustainable development. In the Karakoram region of Pakistan, women are a marginalized gender of the marginalized mountain society, because their access to credit, education, health, capacity building, skill enhancement and employment opportunities is limited due limited availability of public goods, economic resources available to them, mobility constraints due to strict tribal traditions and cultural norms, higher household responsibilities and security issues. In the presence of such constraints, women's participation in economic activities and decision-making processes is limited and their entrepreneurial potential is untapped. Policymakers should design policies that protect women's rights and ensure gender equality and empowerment by providing greater access to basic services, e.g., health, education and financial inclusion, so that they become an earning hand for their children and families.

Moral capacity building of the entrepreneurs is a prerequisite to capture a higher market share in the short run and for the enterprise survival and sustainability in the long run. Production of low-quality and below-standard goods and services are common in most developing countries including Pakistan. This practice not only reduced domestic demand by reducing consumer's satisfaction on domestically produced goods and services but also pushed countries toward huge current account deficits. Therefore, for import substitution and export surplus of developing countries, moral and ethical training programs and awareness campaigns among entrepreneurs should be conducted at the state level. This will not only enlarge the market for domestically produced goods and services in developing countries, but also reduce pressures on the external side of the economy. Moral and ethical capacity building of the entrepreneurs may also help to tackle various socioeconomic and cultural challenges and to bring gender equality in developing countries. Along with moral capacity, building state should regulate and ensure the implementation of pure foods or quality standards rules to maintain food safety and hygiene and to discourage the production of below-standard goods and services.

Along with moral, physical capacity building and skill enhancement of the entrepreneurs are necessary for the efficient utilization of inclusive finance. MFIs should arrange necessary training sessions to educate and develop necessary business and technical skills among entrepreneurs before credit disbursement in order to achieve better and sustained results of the inclusive finance program. MFIs should also develop and improve their monitoring and evaluation (M\&E) mechanism to assess the performance of the entrepreneurial activities on a regular basis. This process should also evaluate market demand for inclusive finance products and investigate mistargeting issues for greater outreach to overcome the issue of unproductive use of inclusive finance funds. 


\subsection{Implications}

As far as theoretical and contextual contributions of the research are concerned, this study is one of the first that expanded the existing body of scientific knowledge by exploring the role of financial inclusion on socioeconomic disaster risks, i.e., economic poverty multidimensional poverty and income inequality separately in the mountain context to determine the exact role of inclusive finance on mountain inhabitants' quality of life in order to achieve the global objectives of sustainable development and Agenda 2030. Secondly, women in the Karakoram region of Pakistan are disadvantaged (evident from the estimated result of female-to-male ratio, i.e., $\beta=0.39$ in the multidimensional poverty model) in many ways, i.e., they experience unequal access to health, education and credit services. Despite their economic contributions to the household (e.g., female-to-male ratio $\beta=-0.7$ ) in the economic poverty model, mountain women remained vulnerable and biased gender of the marginalized mountain society [64], because their participation in socioeconomic and political decision-making is limited. Federal and provincial governments along with other organizations should devise and implement policies, laws to achieve global standards of gender equality and to manage socioeconomic disaster risks on upland women, as there exists a positive synergy between gender equality and sustainable development [65]. Finally, this research provided a baseline data for future research, because primary and secondary data about inclusive finance in Pakistan are limited [66-71].

\subsection{Suggestions for Future Research}

An obvious limitation of this study was the nonavailability of baseline data due to which we could not apply the difference-in-difference method, considered as a superior method of impact evaluation. This study will provide baseline data and enable future researchers to use this superior method in the impact assessment of mountain-specific poverty in the study area. Secondly, women entrepreneurial potential is untapped due to cultural constraints and limited numbers of women-owned enterprises; therefore, future research may also be carried out to analyze the impact of financial inclusion on gender development in the Karakoram valleys of Pakistan.

Author Contributions: Conceptualization, K.U., A.Q.M. and A.S.; Data curation, K.U.; Formal analysis, K.U.; Investigation, K.U.; Methodology, K.U.; Resources, A.S. and S.B.; Software, K.U., A.Q.M. and S.B.; Supervision, A.Q.M. and A.S.; Validation, A.Q.M. and A.S.; Writing—original draft, K.U.; Writing—review \& editing, K.U., A.Q.M., A.S. and S.B. All authors have read and agreed to the published version of the manuscript.

Funding: This research received no external funding.

Conflicts of Interest: The authors declare no conflict of interest.

\section{References}

1. Veith, C.; Shaw, J. Why Invest in Sustainable Mountain Development? FAO: Rome, Italy, 2011; ISBN 978-92-5-107012-3.

2. Bina, O. The green economy and sustainable development: An uneasy balance. Environ. Plan. C Politics Space. 2013, 31, 1023-1047. [CrossRef]

3. Loiseau, E.; Saikku, L.; Antikainen, R.; Droste, N.; Hansjürgens, B.; Pitkänen, K.; Thomsen, M. Green economy and related concepts: An overview. J. Clean. Prod. 2013, 139, 361-371. [CrossRef]

4. Kohler, T.; Balsiger, J.; Rudaz, G.; Debarbieux, B.; Pratt, J.; Maselli, D. Green Economy and Institutions for Sustainable Mountain Development: From Rio 1992 to Rio 2012 and Beyond; Swiss Agency for Development and Cooperation (SDC): Bern, Switzerland, 2015; ISBN 978-3-905835-40-3.

5. Ariza, C.; Maselli, D.; Kohler, T. Mountains: Our Life, Our Future; Progress and Perspectives on Sustainable Mountain Development from Rio 1992 to Rio 2012 and Beyond; SDC and CDE: Bern, Switzerland, 2013; ISBN 978-3-905835-18-2.

6. Emas, R. Brief for GSDR. The Concept of Sustainable Development: Definition and Defining Principles; Florida International University: Miami, FL, USA, 2015.

7. Gerlitz, J.-Y.; Hunzai, K.; Hoermann, B. Mountain poverty in the Hindu-Kush Himalayas. Can. J. Dev. Stud. 2012, 33, 250-265. [CrossRef] 
8. Kiran, H.; Jean-Yves, G.; Brigitte, H. Understanding Mountain Poverty in the Hindu Kush-Himalayas: Regional Report for Afghanistan, Bangladesh, Bhutan, China, India, Myanmar, Nepal, and Pakistan; International Centre for Integrated Mountain Development (ICIMOD): Kathmandu, Nepal, 2011; ISBN 978-92-9115-213-1.

9. UNISDR CRED. The Human Cost of Natural Disasters: A Global Perspective; Centre for Research on the Epidemiology of Disaster (CRED): Brussels, Belgium, 2015.

10. Khalid, M.; Kaushik, G. Food Security in Mountains: Challenges and Sustainable Strategies. 2008. Available online: http://lib.icimod.org/record/13336/files/1850.pdf (accessed on 25 August 2020).

11. Farrington, J.; Gill, G.J. Combining growth and social protection in weakly integrated rural areas. Economist 2002, 75. Available online: https://www.files.ethz.ch/isn/91372/NRP79.pdf (accessed on 12 November 2020).

12. Baloch, A.; Shah, S.Z.; Noor, Z.M.; Magsi, H.B. The nexus between income inequality, economic growth and environmental degradation in Pakistan. GeoJournal 2018, 83, 207-222. [CrossRef]

13. Kifayat, U.; Khan, F.; Ejaz, A. Determinants of poverty in mountain region of Gilgit-Baltistan, Pakistan. Dev. Ctry. Stud. 2014, 4, 10-19.

14. Aduda, J.; Kalunda, E. Financial inclusion and financial sector stability with reference to Kenya: A review of literature. J. Appl. Financ. Bank. 2012, 2, 95-120.

15. Dev, S.M. Financial inclusion: Issues and challenges. Econ. Political Wkly. 2006, 41, 4310-4313.

16. Benz, A. Framing modernization interventions: Reassessing the role of migration and translocality in sustainable mountain development in Gilgit-Baltistan, Pakistan. Mt. Res. Dev. 2016, 36, 141-152. [CrossRef]

17. Ramaswamy, A.; Krishnamoorthy, A. The Nexus Between Microfinance \& Sustainable Development: Examining The Regulatory Changes Needed For Its Efficient Implementation. Eur. J. Sustain. Dev. 2016, $5,453-460$.

18. Muñoz-Torres, M.; Izquierdo, F.M.A.; Lirio, R.J.M.; Ferrero-Ferrero, I.; Olmedo, E.E. Responsible Investment as Market Driver for Sustainable Development. Univ. Oslo Fac. Law Res. Pap. 2017, 24. [CrossRef]

19. Joshi, M.Y.; Flacke, J.; Schwarz, N. Do microfinance institutes help slum-dwellers in coping with frequent disasters? An agent-based modelling study. Int. J. Disaster Risk Reduct. 2020, 101627. [CrossRef]

20. PMN. Achieving Together; Pakistan Microfinance Network: Islamabad, Pakistan, 2017.

21. Janjua, P.; Muhammad, M.; Ullah, K. Impact of village group financial services of living standard of house hold in gilgit: A casestudy of the First Microfinance Bank Gilgit. Pak. Bus. Rev. 2013, 15, $27-49$.

22. Muhammad, M.; Janjua, P.Z.; Ullah, K. Impact of Village Group Financial Services on Women Empowerment and Poverty: A Case Study of the First Micro Finance Bank Gilgit. Dialogue 2011, 6, 384-397.

23. Boonperm, J.; Haughton, J.; Khandker, S.R. Does the Village Fund matter in Thailand? Evaluating the impact on incomes and spending. J. Asian Econ. 2013, 25, 3-16. [CrossRef]

24. Alkire, S.; Roche, J.M.; Ballon, P.; Foster, J.; Santos, M.E.; Seth, S. Multidimensional Poverty Measurement and Analysis; Oxford University Press: Oxford, UK, 2015; ISBN 978-0-19-968949-1.

25. Alkire, S.; Foster, J. Counting and multidimensional poverty measurement. J. Public Econ. 2011, 95, 476-487. [CrossRef]

26. Idrees, M.; Baig, M. An Empirical Analysis of Multidimensional Poverty in Pakistan. FWU J. Soc. Sci. 2017, 11, 297-309.

27. Carvalho, L.S.; Meier, S.; Wang, S.W. Poverty and economic decision-making: Evidence from changes in financial resources at payday. Am. Econ. Rev. 2016, 106, 260-284. [CrossRef]

28. Ravallion, M. Handbook of Development Economics; Elsevier: Amsterdam, The Netherlands, 2007. [CrossRef]

29. Agbola, F.W.; Acupan, A.; Mahmood, A. Does microfinance reduce poverty? New evidence from Northeastern Mindanao, the Philippines. J. Rural Stud. 2017, 50, 159-171. [CrossRef]

30. Ravallion, M. Assessing the Poverty Impact of an Assigned Program: The Impact of Economic Policies on Poverty and Income Distribution: Evaluation Techniques and Tools; UNICEF: New York, NY, USA, 2003.

31. Baker, J.L. A Handbook for Evaluating the Impact of Development Projects on Poverty; World Bank Group: Washington, DC, USA, 2000. [CrossRef]

32. Datt, G.; Jolliffe, D. Poverty in Egypt: Modeling and policy simulations. Econ. Dev. Cult. Chang. 2005, 53, 327-346. [CrossRef]

33. Cheema, A.; Khalid, L.; Patnam, M. The geography of poverty: Evidence from the Punjab. Lahore J. Econ. 2008, 13, 163-188. [CrossRef]

34. Kakwani, N.; Son, H.H.; Qureshi, S.K.; Arif, G. Pro-poor growth: Concepts and measurement with country case studies [with comments]. Pak. Dev. Rev. 2003, 42, 417-444. [CrossRef] 
35. Bidani, B.; Datt, G.; Lanjouw, J.O.; Lanjouw, P. Specifying poverty lines: How and why. In Proceedings of the Asia and Pacific Forum on Poverty: Reforming Policies and Institutions for Poverty Reduction, Manila, Philippines, 5-9 February 2001; Asian Development Bank: Manila, Philippines, 2001.

36. Hyder, A. National Poverty Report; Ministry of Planning Development \& Reforms: Isalamabad, Pakistan, 2016.

37. Wasti, E. Pakistan Economic Survey; Finance Division Government of Pakistan: Islamabad, Pakistan, 2019.

38. Foster, J.; Greer, J.; Thorbecke, E. A class of decomposable poverty measures. Econom. J. Econom. Soc. 1984, 52, 761-766. [CrossRef]

39. Ahmed, F.; Idris, C.S.; Begum, R.A. Impact of microcredit on poverty alleviation among rural women: A case study of Panchagarh District in Bangladesh. Afr. J. Bus. Manag. 2011, 5, 7111-7119.

40. Bastos, A.; Casaca, S.F.; Nunes, F.; Pereirinha, J. Women and poverty: A gender-sensitive approach. J. Socio Econ. 2009, 38, 764-778. [CrossRef]

41. Sen, A. Development as Freedom; Oxford University Press: New Delhi, India, 1999.

42. Todaro, M.P.; Smith, S.C. Economic Development; Pearson: Harlow, UK, 2015.

43. Hermes, N. Does microfinance affect income inequality? Appl. Econ. 2014, 46, 1021-1034. [CrossRef]

44. Lacalle-Calderon, M.; Larrú, J.M.; Garrido, S.R.; Perez-Trujillo, M. Microfinance and income inequality: New macrolevel evidence. Rev. Dev. Econ. 2019, 23, 860-876. [CrossRef]

45. Gujarati, D.N. Basic Econometrics; Tata McGraw-Hill Education: New Dehli, India, 2009.

46. Adugna, E.; Sileshi, M. Determinants of poverty in agro-pastoral societies of Southern Ethiopia. Livest. Res. Rural Dev. 2013, 25, 20.

47. Hussain, J.G.; Mahmood, S. Impact of Microfinance loan on poverty reduction amongst Female Entrepreneurship in Pakistan. In Proceedings of the Cambridge Business E Economics Conference, Cambridge, UK, 27-28 June 2012; College Cambridge University: Cambridge, UK, 2012; pp. 1-34, ISBN 9780974211428.

48. Muhammedhussen, M. Determinants of Rural Income Poverty in Ethiopia: Case Study of Villages in Dodola District. Glob. J. Manag. Bus. Res. 2015, 15, 25-28.

49. Khan, M.H. Methods of Assessment of Rural Poverty, Pojects and Programme Impact; Rural Support Program Network: Isalamabad, Pakistan, 2004.

50. Yamane, T. Elemantary Sampling Theory; Printıce-Hall: Engle Wood Clifts, NJ, USA, 1967.

51. Agrawala, S.; Carraro, M. Assessing the Role of Microfinance in Fostering Adaptation to Climate Change; CMCC Research Paper no. 91; OECD: Paris, France, 2010. [CrossRef]

52. Ali, I.; Islam, M.S.; Hatta, Z.A. Microfinance Helps to Rural Women for Poverty Reduction in the District of Bogra, Bangladesh. Sociol. Anthropol. 2015, 3, 218-225. [CrossRef]

53. Ramakrishnan, P. Sustainable mountain development: The Himalayan tragedy. Curr. Sci. 2007, 92, 308-316.

54. Muñoz-Torres, M.J.; Fernández-Izquierdo, M.Á.; Rivera-Lirio, J.M.; Escrig-Olmedo, E. Can environmental, social, and governance rating agencies favor business models that promote a more sustainable development? Corp. Soc. Responsib. Environ. Manag. 2019, 26, 439-452. [CrossRef]

55. García-Pérez, I.; Muñoz-Torres, M.J.; Fernández-Izquierdo, M.Á. Microfinance institutions fostering sustainable development. Sustain. Dev. 2018, 26, 606-619. [CrossRef]

56. Mazumder, M.S.U. Role of microfinance in sustainable development in rural Bangladesh. Sustain. Dev. 2015, 23, 396-413. [CrossRef]

57. Blondeau, N. Microfinance An Instrument of Sustainable Development. Ètudes 2006, 9, 1-11.

58. Davies, H.T.O.; Crombie, I.K.; Tavakoli, M. When can odds ratios mislead? Bmj 1998, 316, 989-991. [CrossRef]

59. Chowdhury, A. Microfinance as a Poverty Reduction Tool: A Critical Assessment; UNDESA Working Paper no. 89; UNDESA: New York, NY, USA, 2009; pp. 1-13. [CrossRef]

60. Hashmi, A.A.; Sial, M.H.; Hashmi, M.H.; Anwar, T. Trends and Determinants of Rural Poverty: A Logistic Regression Analysis of Selected Districts of Punjab [with Comments]. Pak. Dev. Rev. 2008, 47, 909-923. [CrossRef]

61. McCulloch, N.; Baulch, B. Simulating the impact of policy upon chronic and transitory poverty in rural Pakistan. J. Dev. Stud. 2000, 36, 100-130. [CrossRef]

62. Hamidazada, M.; Cruz, A.M.; Yokomatsu, M. Vulnerability Factors of Afghan Rural Women to Disasters. Int. J. Disaster Risk Sci. 2019, 10, 573-590. [CrossRef]

63. Dunford, C. Building better lives: Sustainable integration of microfinance and education in child survival, reproductive health, and HIV/AIDS prevention for the poorest entrepreneurs. J. Microfinanc. ESR Rev. 2001, $3,1-25$. 
64. Nawaz, S. Microfinance and poverty reduction: Evidence from a village study in Bangladesh. J. Asian Afr. Stud. 2010, 45, 670-683. [CrossRef] [PubMed]

65. Gillani, S.Y.M.; Rehman, H.U.; Gill, A.R. Unemployment, poverty, inflation and crime nexus: Cointegration and causality analysis of Pakistan. Pak. Econ. Soc. Rev. 2009, 47, 79-98.

66. Aman, J.; Abbas, J.; Mahmood, S.; Nurunnabi, M.; Bano, S. The Influence of Islamic Religiosity on the Perceived Socio-Cultural Impact of Sustainable Tourism Development in Pakistan: A Structural Equation Modeling Approach. Sustainability 2019, 11, 3039. [CrossRef]

67. Sherpa, D. New Vulnerabilities for Mountain Women: A Different Light on the Greater Himalaya; Status Report; International Centre for Integrated Mountain Development (ICIMOD): Kathmandu, Nepal, 2007.

68. Jackson, C. Doing what comes naturally? Women and environment in development. World Dev. 1993, 21, 1947-1963. [CrossRef]

69. Ghalib, A.K.; Malki, I.; Imai, K.S. The impact of microfinance and its role in easing poverty of rural households: Estimations from Pakistan. Kobe Univ. 2011, 9, 1-37.

70. Ghalib, A.K.; Malki, I.; Imai, K.S. Microfinance and household poverty reduction: Empirical evidence from rural Pakistan. Oxf. Dev. Stud. 2015, 43, 84-104. [CrossRef]

71. Hussein, M.; Hussain, S. The Impact of Micro Finance on Poverty and Gender Equity: Approaches and Evidence from Pakistan; Pakistan Microfinance Network: Islamabad, Pakistan, 2003.

Publisher's Note: MDPI stays neutral with regard to jurisdictional claims in published maps and institutional affiliations. 